\title{
Determination of Antihypertensive Small Peptides, Val-Tyr and Ile-Val-Tyr, by Fluorometric High-Performance Liquid Chromatography Combined with a Double Heart-Cut Column-Switching Technique
}

\author{
Takao Ueno, Mitsuru Tanaka, Toshiro Matsui, ${ }^{\dagger}$ and Kiyoshi Matsumoto \\ Department of Food Science and Technology, Faculty of Agriculture, Kyushu University, \\ 6-10-1 Hakozaki, Fukuoka 812-8581, Japan
}

\begin{abstract}
A double column-switching HPLC method with naphthalene-2,3-dialdehyde (NDA) was applied for determination of two plasma antihypertensive peptides, Val-Tyr (VY) and Ile-Val-Tyr (IVY). After a first separation on a Phe-ODS column, double heart-cuts of the retention time corresponding to NDA-VY and NDA-IVY elutions were successfully separated on an analytical ODS column: $60 \%$ acetonitrile in $0.1 \%$ trifluoroacetic acid containing $5 \mathrm{mM}$ sodium 1-octanesulfonate at $1.0 \mathrm{~mL} / \mathrm{min}$. Within-run coefficients of variation were $1.73 \%$ and $4.73 \%$ for VY and IVY, respectively.
\end{abstract}

(Received May 6, 2005; Accepted June 2, 2005)

To date, many natural peptides possessing an angiotensin Iconverting enzyme (ACE, EC 3.4.15.1) inhibitory action have been identified, ${ }^{1}$ among which some peptides were clinically proven to show an antihypertension effect for borderline hypertensives. ${ }^{2,3}$ The clinical evidence led us to further study of the underlying antihypertensive mechanism of ACE inhibitory peptides. However, there was little study on elucidating the mechanism induced by active peptides, ${ }^{4,5}$ due to the lack of an adequate assay system for evaluating the bioavailability of small peptides.

In our series of studies regarding ACE inhibitory peptides from natural sources, we have identified some antihypertensive peptides. Among them, Val-Tyr (VY; $\left.\mathrm{IC}_{50}, 26 \mu \mathrm{M}\right)$ from sardine muscle hydrolysate ${ }^{6}$ and Ile-Val-Tyr (IVY; IC $_{50}, 0.48$ $\mu \mathrm{M})$ from wheat germ hydrolysate ${ }^{7}$ showed a significant antihypertensive effect in humans ${ }^{2}$ and/or in rats. ${ }^{8}$ In particular, IVY, one of the strongest natural ACE inhibitors showed a unique metabolic pathway in rat and human blood systems; namely, IVY was preferably degraded to produce antihypertensive VY in blood by the action of plasma aminopeptidases, resulting in a prolonged blood pressure lowering in hypertensive rats. $^{8}$ Thus, to clarify the antihypertensive mechanism of IVY, it seems to be worthwhile to determine plasma VY and IVY levels simultaneously.

A common method suitable for peptide determination was an ELISA $^{9}$ or surface plasmon resonance (SPR) assay, ${ }^{10}$ but such an assay was not widely applicable for larger peptides exerting antigenicity. In our previous report, ${ }^{11}$ we have proposed a fluorometric column-switching HPLC method for small ACE inhibitory peptides without antigenicity. A sensitive determination of VY in rat and human plasma was thus achieved at the concentration of $>100 \mathrm{fmol} / \mathrm{mL}$-plasma. Hence, in the present study, we developed a double column-switching HPLC method for the determination of VY and IVY in blood in a one-run assay.

\footnotetext{
† To whom correspondence should be addressed.

E-mail: tmatsui@agr.kyushu-u.ac.jp
}

\section{Experimental}

\section{Reagents and materials}

VY was purchased from Kokusan Chemical Works (Tokyo, Japan). IVY was synthesized with an Fmoc-solid method. Naphthalene-2,3-dialdehyde (NDA) as a fluorometric reagent was purchased from Funakoshi (Tokyo, Japan). Acetonitrile $\left(\mathrm{CH}_{3} \mathrm{CN}\right)$ was of HPLC grade (Kantokagaku, Tokyo, Japan). Deionized water was prepared by a Milli-Q system (Millipore, Japan). Sodium 1-octanesulfonate (SOS) was purchased from Nacalai Tesque (Kyoto, Japan). All other chemicals were of analytical reagent-grade and were used without further purification.

\section{Instruments}

According to our proposed column-switching HPLC system with a heart-cut technique, ${ }^{11}$ we developed a system for the determination of two peptides in a one-run assay (Fig. 1). The system was composed of a solvent delivery system of two pumps (A and B) (LC-10A, Shimadzu), an automated gradient controller (SCL-9A, Shimadzu), a column oven (CTO-10A, Shimadzu), a manual four-port switching valve (HPV-4, GL Sciences), a UV-VIS detector (UV2075, Nippon Bunko), and a fluorescence detector (FP2025 Plus, Nippon Bunko).

\section{Derivatization of peptide with NDA}

NDA derivatization was performed with a slight modification of our previously reported method. ${ }^{12}$ To obtain a maximal fluorescent intensity of NDA-peptide product, we investigated the effects of reaction time and temperature prior to the development of a double column-switching HPLC method. The NDA-derivatizing reaction condition in this experiment was as follows: VY or IVY dissolved in $50 \mu \mathrm{L} 20 \mathrm{mM}$ borate buffer (pH 9.5) was added to $10 \mu \mathrm{L} 10 \mathrm{mM}$ sodium cyanide in the borate buffer, followed by the addition of $50 \mu \mathrm{L} 0.1 \mathrm{mM}$ NDA solution in methanol in a 96-well microplate. After the solution was incubated several times for up to $90 \mathrm{~min}$ at $25^{\circ} \mathrm{C}$ or for 60 


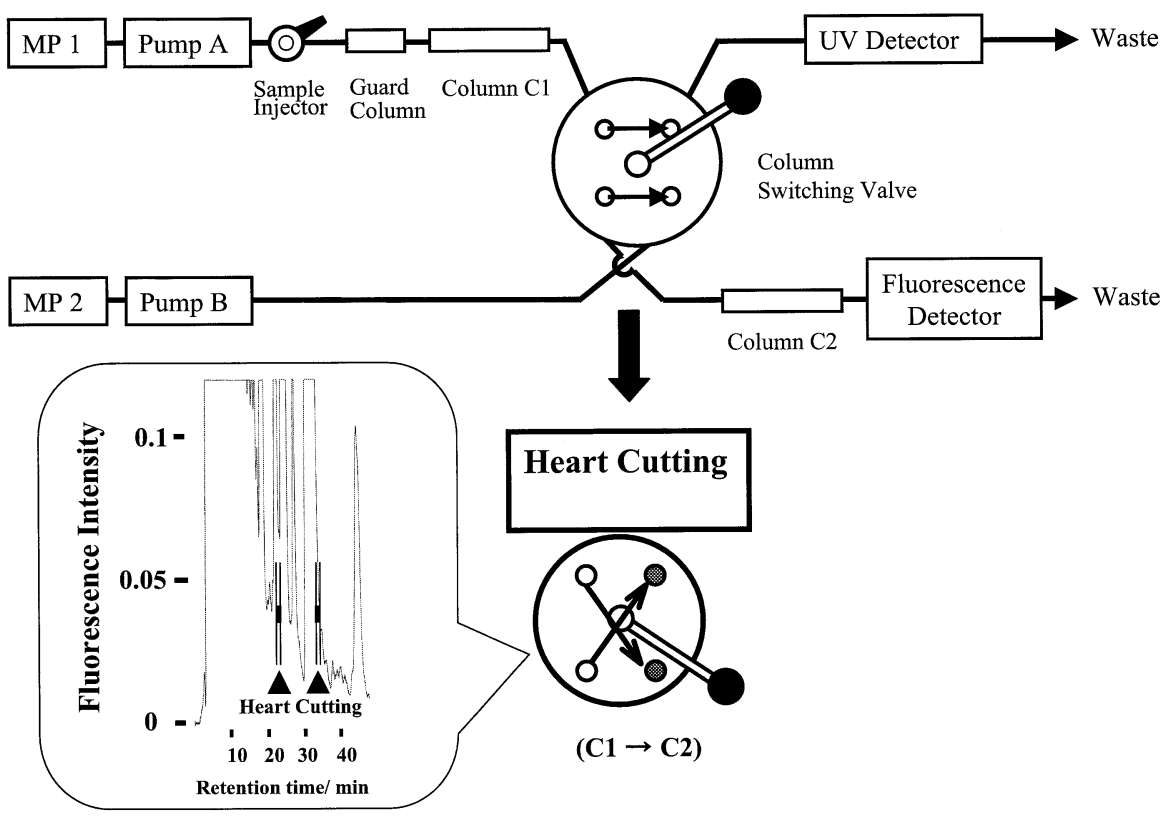

Fig. 1 Schematic representation of the column-switching HPLC system for the determination of IVY and VY in plasma. A sample $(50 \mu \mathrm{L})$ was loaded into the $\mathrm{C} 1$ column. When VY-NDA or IVYNDA was eluted on the $\mathrm{C} 1$ column, each eluting zone of retention times \pm 0.4 min was heart-cut as seen in the inserted HPLC chromatogram on the $\mathrm{C} 1$ column. Each zone was then transferred to $\mathrm{C} 2$ analytical column by valve operation and the introduced eluate was separated on $\mathrm{C} 2$ followed by fluorescence detection. MP: mobile phase.

min at several temperatures up to $35^{\circ} \mathrm{C}$, the intensity of the NDA-derivative was detected by a Multilabel counter (Wallac 1420 ARVOsx, Perkin Elmer) with an excitation at $390 \mathrm{~nm}$ and an emission at $460 \mathrm{~nm}$.

\section{Column-switching HPLC system}

Our column-switching HPLC system was composed of a clean-up column (C1) and an analytical column (C2), as shown in Fig. 1. The $\mathrm{C} 1$ was a Cosmosil $5 \mathrm{Ph}$ column and the $\mathrm{C} 2$ was a Cosmosil 5C $\mathrm{C}_{18}$-ARII column (each column: $5 \mu \mathrm{m}, 4.6 \mathrm{~mm} \times 250$ $\mathrm{mm}$ i.d., Nacalai Tesque). A Cosmosil $5 \mathrm{Ph}$ guard column (5 $\mu \mathrm{m}, 4.6 \mathrm{~mm} \times 10 \mathrm{~mm}$ i.d.) was connected in front of the $\mathrm{C} 1$ column. Both columns were operated at $35^{\circ} \mathrm{C}$. The mobile phase for $\mathrm{C} 1$ (MP1) was an $\mathrm{CH}_{3} \mathrm{CN}$-water mixture containing $0.1 \%$ trifluoroacetic acid (TFA) at a flow rate of $1.0 \mathrm{~mL} / \mathrm{min}$. The linear gradient system of MP1 used $35.3-40.6 \% \mathrm{CH}_{3} \mathrm{CN}$ within $50 \mathrm{~min}$. The mobile phase for C2 (MP2) was $\mathrm{CH}_{3} \mathrm{CN}$-water/0.1\% TFA containing $5 \mathrm{mM}$ SOS. Optimal elution conditions for separation of two peptides are discussed in the text. Retention times of NDA-VY and NDA-IVY on the C1 were checked by an UV detector at $220 \mathrm{~nm}$ prior to the column switching. The injection volume to the system was fixed at $50 \mu \mathrm{L}$ throughout the experiment.

\section{Preparation of rat plasma sample}

Male Sprague Dawley (SD) rats (Charles River, 9 weeks of age; $n=6$ ) were used for IVY administration study. A single oral administration of $10 \mathrm{mg} / \mathrm{kg}$ IVY dissolved in $1 \mathrm{~mL}$ saline solution was performed by gavage. A blood sample (ca. $1 \mathrm{~mL})$ was taken from the abdominal aorta into a heparinized tube at 1 $\mathrm{h}$ after the administration. After an immediate centrifugation at $3500 \mathrm{~g}$ for $15 \mathrm{~min}\left(4^{\circ} \mathrm{C}\right), 10 \mathrm{mM}$ aprotinin (Sigma-Aldrich, St. Louis, MO, USA), $20 \mathrm{mM}$ chymostatin (Sigma-Aldrich), and 1 mM EDTA-2Na were added to the obtained plasma to avoid any excess hydrolyses by plasma peptidases. ${ }^{13}$ Then, $0.5 \mathrm{~mL}$
$10 \%(\mathrm{w} / \mathrm{v})$ trichloroacetic acid was added to $1.0-\mathrm{mL}$ plasma sample to remove proteins, followed by a centrifugation at $10000 \mathrm{~g}$ for $20 \mathrm{~min}\left(4^{\circ} \mathrm{C}\right)$. Then, a solid-phase extraction of the supernatant with a Sep-Pak Plus C18 cartridge (Waters, Milford, Massachusetts, USA) was performed. An aliquot (200 $\mu \mathrm{L}$ ) of the supernatant was applied onto the column and eluted with $3 \mathrm{~mL} 35 \% \mathrm{CH}_{3} \mathrm{CN}$ in $0.1 \%$ TFA to obtain a fraction containing VY and IVY. A further purification of the eluate was done with a reversed HPLC system (Shimadzu LC-9A, column: Cosmosil 5C 18 -ARII, $5 \mu \mathrm{m}, 4.6 \mathrm{~mm} \times 250 \mathrm{~mm}$ i.d.) The eluate dissolved in $60 \mu \mathrm{L} 5 \% \mathrm{CH}_{3} \mathrm{CN}$ in $0.1 \%$ TFA was injected to the HPLC system (injection volume: $50 \mu \mathrm{L}$ ). The mobile phase for the HPLC system was $\mathrm{CH}_{3} \mathrm{CN}$-water/0.1\% TFA with a linear $\mathrm{CH}_{3} \mathrm{CN}$ gradient $(5-23.6 \%, 62 \mathrm{~min})$ at a flow rate of $0.8 \mathrm{~mL} / \mathrm{min}$. Each zone of the retention of VY $(22.7 \pm 0.04 \mathrm{~min})$ and IVY $(46.6 \pm 0.01 \mathrm{~min})$ under the described HPLC condition was combined so as to attempt a one-run assay of plasma VY and IVY determinations, and then the sample was subjected to the NDA derivatization. The rat experiment was carried out under the Guidance for Animal Experiments in the Faculty of Agriculture and in the Graduate Course of Kyushu University and the Law (No. 105, 1973) and Notification (No. 6, 1980 of the Prime Minister's Office) of the Japanese Government.

\section{Results and Discussion}

Optimization of NDA derivatization of VY and IVY

NDA is known to be a useful fluorescent-derivatizing reagent of compounds with a primary amino group. ${ }^{14,15}$ However, few applications of NDA to peptide-derivatization have been reported, except for $\mathrm{VY}^{13}$ and Gly-Gly-Gly. ${ }^{16}$ Therefore, the optimal reaction conditions of VY and IVY with NDA were examined. Figure 2 shows the effects of NDA derivatization 

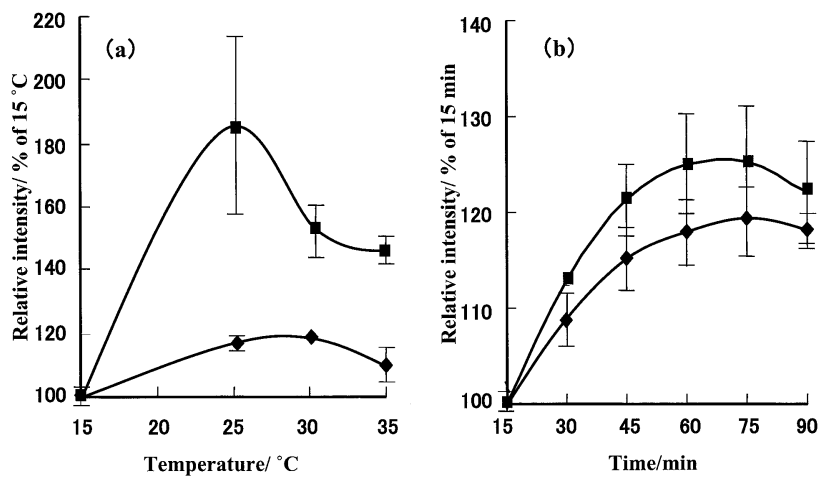

Fig. 2 Effects of temperature (a) and time (b) on the derivatization reaction of VY ( $)$ and IVY ( $)$ with NDA. A relative intensity (\%) of NDA-peptide at a given condition to that at $15^{\circ} \mathrm{C}$ for $60 \mathrm{~min}$ (a) or at $25^{\circ} \mathrm{C}$ for $15 \mathrm{~min}$ (b) was used for evaluating NDA-peptide derivatization.

time and temperature on the fluorescent intensity of VY and IVY. As shown in Fig. 2a, NDA-derivatization of dipeptide, VY, was greatly affected by a reaction temperature that ranged from $15-35^{\circ} \mathrm{C}$, showing a maximal intensity at $25^{\circ} \mathrm{C}$, whereas little influence of the temperature was observed for IVY derivatization. The effect of time on derivatization was then investigated at $25^{\circ} \mathrm{C}$. As shown in Fig. 2b, fluorescent intensities of both peptides increased with time up to $60 \mathrm{~min}$, and thereafter reached a plateau. Therefore, NDAderivatization of VY and IVY at $25^{\circ} \mathrm{C}$ for 60 min was applied throughout the experiment. On the whole, a fluorescence intensity of IVY was much lower than that of VY. A similar poor detection of tripeptides rather than dipeptides was reported by DeMotigny et al., ${ }^{16}$ who concluded that this was due to an unexpected side-production during the NDA reaction with tripeptides that led to the formation of imidazolidinone.

\section{Establishment of a double-column switching HPLC}

Our first attempt to determine NDA-VY and NDA-IVY in a one-run assay by applying a double column-switching HPLC method was done on the basis of our proposed single columnswitching HPLC condition for NDA-VY. ${ }^{11}$ In detail, for analytical column (C2) separation, an isocratic elution with $60 \%$ $\mathrm{CH}_{3} \mathrm{CN} / 0.1 \%$ TFA at a flow rate of $0.4 \mathrm{~mL} / \mathrm{min}$ was performed using each standard solution $(2 \mathrm{pmol} / \mathrm{mL}$ of $\mathrm{VY}$ and $3 \mathrm{pmol} / \mathrm{mL}$ of IVY). Though data are not shown, a reproducible elution of NDA-VY and NDA-IVY was observed on C1 column at the conditions described in the Experimental section; retention times of NDA-VY and NDA-IVY on C1 were $23.9 \pm 0.03 \mathrm{~min}$ and $37.3 \pm 0.05 \mathrm{~min}$, respectively. Then, by heart-cutting the zone of retention times $\pm 0.4 \mathrm{~min}$ corresponding to NDA-VY and NDA-IVY elutions on $\mathrm{C} 1$ twice, we observed a poor separation profile of each NDA-peptide. The poor separation was due to an overlap of NDA-VY with ghost-pressure peak induced by the second switching, and an overlap of NDA-IVY with interfering peaks. To improve these separation profiles, we modified the MP2 solvent system. The application of a lower concentration of $50 \% \quad \mathrm{CH}_{3} \mathrm{CN}$ resulted in a slight improvement of separations of both peptides, but a broad peak of NDA-IVY was still observed due to the low $\mathrm{CH}_{3} \mathrm{CN}$ concentration. Thus, our next trial was to change the flow rate of MP2 at a fixed concentration of $60 \% \mathrm{CH}_{3} \mathrm{CN}$. As a result, increasing the flow rate gave a sufficient separation for both NDA-peptides. A complete and rapid detection was observed at

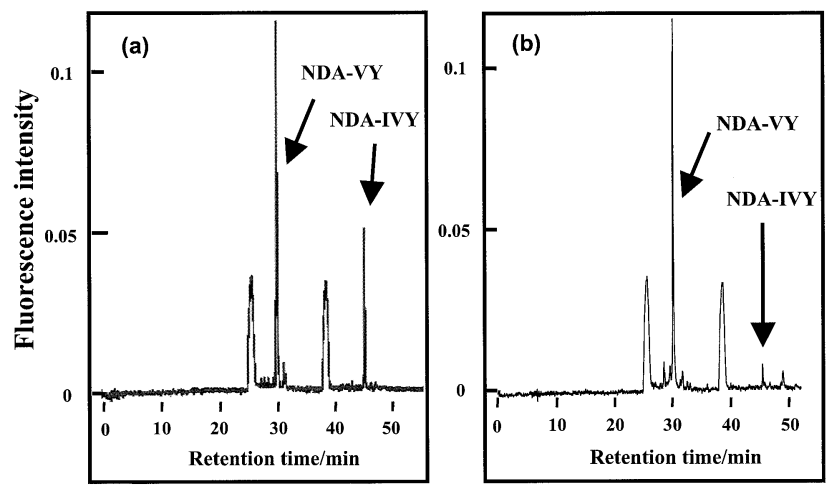

Fig. 3 Application of a double column-switching method to detect VY and IVY peptides in a one-run assay. (a) Sample: standard VY ( $2 \mathrm{pmol} / \mathrm{mL}$ ) and IVY (3 pmol/mL), elution condition for MP2: $60 \%$ $\mathrm{CH}_{3} \mathrm{CN} / 0.1 \%$ TFA containing $5 \mathrm{mM} \mathrm{SOS}$; flow rate, $1.0 \mathrm{~mL} / \mathrm{min}$. (b) Sample: IVY (10 mg/kg)-administered SD rat plasma at $1 \mathrm{~h}$, elution condition for MP2: $60 \% \mathrm{CH}_{3} \mathrm{CN} / 0.1 \%$ TFA containing $5 \mathrm{mM}$ SOS; flow rate, $1.0 \mathrm{~mL} / \mathrm{min}$.

$1.0 \mathrm{~mL} / \mathrm{min}$ (Fig. 3a). At the optimal MP2 condition, NDA-VY and NDA-IVY were eluted on C2 at $31.8 \pm 0.15 \mathrm{~min}$ and $47.8 \pm$ $0.15 \mathrm{~min}$, respectively. A complete separation of each NDApeptide was also observed in IVY-administered SD rat plasma (Fig. 3b), establishing the validity of the present double columnswitching HPLC method for simultaneous determination of plasma VY and IVY levels.

\section{Validation of performance}

Under the established HPLC conditions, linear calibration curves were obtained for VY and IVY in the concentration range of $0-10 \mathrm{pmol} / \mathrm{mL}$ (data are not shown). Each equation for the regression line was as follows: VY, $y=12494 x-259$ (correlation coefficient, $r=0.998)$; IVY, $y=4360 x-165(r=$ 0.991 ), where $x$ is the concentration in $\mathrm{pmol} / \mathrm{mL}$ and $y$ is the peak height $(\mu \mathrm{V} s)$ of NDA-peptide. Within-runs $(n=3)$ and between-day precisions (one assay on each of three separate days) for VY and IVY determinations were examined by the analysis of each peptide standard $(5 \mathrm{pmol} / \mathrm{mL})$. Within-run C.V. (coefficient of variation) values for VY and IVY were $1.73 \%$ and $4.73 \%$, respectively, and between-day C.V. values for VY and IVY were $10.6 \%$ and $4.78 \%$, respectively. The recoveries of peptides from spiked $(1 \mathrm{pmol} / \mathrm{mL})$ rat plasma samples were $92.1 \pm 12.0 \%$ for VY and $92.4 \pm 12.6 \%$ for IVY, respectively. The detection limits of each analyte were 38 $\mathrm{fmol} / \mathrm{mL}$ and $756 \mathrm{fmol} / \mathrm{mL}$ for VY and IVY, respectively $(S / N>$ 2).

\section{Application for IVY-administered rat plasma}

Figure $3 \mathrm{~b}$ shows a typical HPLC chromatogram of IVYadministered plasma $1 \mathrm{~h}$ after the administration by the double NDA column-switching HPLC method. As shown in Fig. 3b, we successfully detected IVY and its degraded VY peptide in rat plasma in a one-run assay without any interference. This finding also revealed that ACE inhibitory tripeptide IVY was absorbed intact, and then degraded to $\mathrm{VY}$ in the rat blood system. The amount of IVY absorption and the production of $\mathrm{VY}$ at $1 \mathrm{~h}$ was calculated to be $1.8 \pm 0.4 \mathrm{pmol} / \mathrm{mL}$-plasma and $1.2 \pm 0.2 \mathrm{pmol} / \mathrm{mL}$-plasma, respectively. In a VY $(10 \mathrm{mg} / \mathrm{kg})-$ administration study in 18-wk spontaneously hypertensive rats, we observed an intact absorption of VY at a concentration of $3.7 \pm 0.04 \mathrm{pmol} / \mathrm{mL}$-plasma at $1 \mathrm{~h}$ as well as a potent 
antihypertensive effect. ${ }^{17}$ Although the plasma VY concentration in the IVY-administration study was $c a$. 1/3-fold lower than that in the VY-administration one, the present finding provided by our proposed double column-switching HPLC method demonstrated for the first time that IVY intake would be sufficient to improve hypertension due to its intact absorption and the subsequent production of antihypertensive dipeptide VY in the circulatory system.

\section{Acknowledgements}

This study was in part supported by a Grant-in-Aid from the Ministry of Education, Science, Sports and Culture of Japan (No. 15380094).

\section{References}

1. T. Matsui and K. Matsumoto, Peptide Protein Res., 2001, 4, 113.

2. T. Kawasaki, E. Seki, K. Osajima, M. Yoshida, K. Asada, T. Matsui, and Y. Osajima, J. Human Hypertens., 2000, 14, 519.

3. Y. Hata, M. Yamamoto, M. Ohni, K. Nakajima, Y. Nakamura, and T. Takano, Am. J. Clin. Nutr., 1996, 64, 767.

4. T. Matsui, A. Hayashi, K. Tamaya, K. Matsumoto, T. Kawasaki, K. Murakami, and K. Kimoto, Clin. Exp. Pharmacol. Physiol., 2003, 30, 262.
5. T. Matsui, T. Ueno, M. Tanaka, H. Oka, T. Miyamoto, K. Osajima, and K. Matsumoto, Hypertension Res., 2005, accepted.

6. H. Matsufuji, T. Matsui, E. Seki, K. Osajima, M. Nakashima, and Y. Osajima, Biosci., Biotechnol., Biochem., 1994, 58, 2244.

7. T. Matsui, C. Li, and Y. Osajima, J. Pept. Sci., 1999, 5, 289.

8. T. Matsui, C. Li, T. Tanaka, T. Maki, Y. Osajima, and K. Matsumoto, Biol. Pharm. Bull., 2000, 23, 427.

9. R. H. Abhold and J. W. Harding, J. Pharmacol. Exp. Ther., 1988, 245, 171.

10. T. Sakai, K. Shinahara, A. Torimaru, H. Tanaka, Y. Shiyama, and K. Matsumoto, Anal. Sci., 2004, 20, 279.

11. T. Matsui, K. Tamaya, T. Kawasaki, and Y. Osajima, J. Chromatogr., B, 1999, 729, 89.

12. H. Matsufuji, T. Matsui, T Oki, T. Kawasaki, and Y. Osajima, Bunseki Kagaku, 1995, 44, 783.

13. T. Matsui, K. Tamaya, E. Seki, K. Osajima, K. Matsumoto, and T. Kawasaki, Clin. Exp. Pharmacol. Phys., 2002, 29, 204.

14. M. N. Monoj, J. R. Mark, and T. B. Ronald, J. Pharm. Biomed. Anal., 1997, 15, 945.

15. Z. Y. Jerry, C. K. Bastian, D. M. Randy, F. S. John, and T. B. Ronald, J. Chromatogr., B, 2002, 780, 269.

16. P. DeMotigny, C. M. Riley, L. A. Sternson, and J. F. Stobaugh, J. Pharm. Biomed. Anal., 1990, 8, 419.

17. T. Matsui, M. Imamura, H. Oka, K. Osajima, K. Kimoto, T. Kawasaki, and K. Matsumoto, J. Pept. Sci., 2004, 10, 535. 